\begin{tabular}{|l|l|l|}
\hline \multicolumn{2}{|c|}{ PublisherInfo } \\
\hline \hline PublisherName & $:$ & BioMed Central \\
\hline \hline PublisherLocation & $:$ & London \\
\hline \hline PublisherImprintName & $:$ & BioMed Central \\
\hline \hline
\end{tabular}

\title{
Marker of increased cancer risk in benign breast disease
}

\begin{tabular}{|l|l|l||}
\hline \multicolumn{2}{|c|}{ ArticleInfo } \\
\hline \hline ArticleID & $:$ & 3743 \\
\hline \hline ArticleDOI & $:$ & $10.1186 /$ bcr-2000-66706 \\
\hline \hline ArticleCitationID & $:$ & 66706 \\
\hline \hline ArticleSequenceNumber & $:$ & 15 \\
\hline \hline ArticleCategory & $:$ & Paper Report \\
\hline ArticleFirstPage & $:$ & 1 \\
\hline \hline ArticleLastPage & $:$ & 3 \\
\hline \hline & & RegistrationDate : 2000-1-11 \\
\hline ArticleHistory & $:$ & OnlineDate \\
\hline \hline ArticleCopyright & $:$ & Current Science Ltd2000-1-11 \\
\hline \hline ArticleGrants & $:$ & \\
\hline \hline ArticleContext & $:$ & 1305833 \\
\hline \hline
\end{tabular}




\section{Keywords}

Benign breast disease, increased cancer risk, TGF- $\beta$

\section{Introduction}

Transforming growth factor beta (TGF- $\beta$ ) inhibits the division of mammary epithelial cells, and loss ofreponse to TGF- $\beta$ is a common event in tumor progression. Previous studieshave shown that the TGF$\beta$-RII receptor is important in cell regulation byTGF- $\beta$. Breast epithelial hyperplastic lesions lacking atypia (EHLA) areassociated with increased breast cancer risk.

\section{Aims}

To investigate the expression of TGF- $\beta$-RII in EHLA and the risk of breast cancer.

\section{Comments}

Preliminary data that requires further confirmation. Of note, largeconfidence intervals were found in this study. If confirmed, TGF- $\beta$-RIIexpression may help in differentiating large numbers of women with benignbreast disease who are at increased risk of breast cancer and who maybenefit from chemopreventative intervention.

\section{Methods}

A nested case-control study of women from the Nashville Breast Study Cohort was coducted.Biopsyconfirmed EHLA with no history of breast cancer or atypicalhyperplasia who subsequently developed breast cancer $(\mathrm{n}=54)$ were comparedwith controls with EHLA who did not develop breast cancer $(\mathrm{n}=115)$. Archivalparaffin-embedded breast biopsy specimens were analyzed byimmunohistochemistry with antibodies against TGF- $\beta$ - RII. 


\section{Results}

Women with EHLA and 25\%-75\% TGF- $\beta$-RII positive cells or $<25 \%$ TGF- $\beta$-RII positive cells had a 1.98 -fold $(95 \% \mathrm{CI}=0.95-4.1)$ and a3.41-fold $(95 \% \mathrm{CI}=1.2-10)$ increased risk of subsequent breast cancer comparedto women in whom $75 \%$ of lesion cells were TGF- $\beta$-RII positive.

\section{Discussion}

Breast cancer risk was inversely correlated with proportion of cellsexpressing TGF- $\beta$-RII. These results, in combination with known histologicand epidemiologic risk factors, may better define the clinical manangement ofwomen with proliferative breast disease.

\section{References}

1. Chang Jenny, Dupont WD, Simpson JF, Plummer WD, Schuyler PA, Olson SJ, Arteaga CL, Page D: Transforming growth factor- $\beta$ and breast cancer risk in women with mammary epithelial hyperplasia. $\mathrm{J}$ Natl Cancer Inst. 2000, 91: 2096-2101. 